\section{IMPACT OF MICROCREDIT ON WOMEN'S EMPOWERMENT IN SOME SELECTED VILLAGES IN BANGLADESH: EXPLORATION OF CHANGE IN WOMEN'S STATUS AND 'PEACE IN THE FAMILY'}

\author{
Sultan Salah Uddin \\ Alison Dundon ${ }^{* * *}$ \\ Most. Aeysha Sultana ${ }^{* * *}$
}

\begin{abstract}
The empowerment of women has been a primary goal of microcredit programs in Bangladesh: but what empowerment is, or 'should be', is contested terrain, as are causal relationships drawn between the implementation of microfinance and the empowerment of women. This paper explores the connection between microcredit and empowerment through analyzing data of a qualitative study. In this study data were collected from 98 adults (male=30;

* Director (Development), TMSS - a renowned NGO in Bangladesh Email: shafy76@yahoo.com

** School of Social Sciences, Faculty of Arts, The University of Adelaide, South Australia - 5005, Australia Email: alison.dundon@adelaide.edu.au

**** Associate Professor, Department of Psychology, University of Dhaka,Email: aeysha_sultana06@yahoo.com
\end{abstract}

female $=68$ ) with age ranged from 18 to 56 years, through individual interviews, focus group discussions and participant observation for six months period of field work in three villages in Bogura, Bangladesh. The study elicited understandings of empowerment from women engaged in microcredit programs, as well as other members of their households. In the paper, we argue that exploring local contexts for, and meanings of, empowerment is crucial for assessing the criteria on which the success (or failure) of microcredit or empowerment is determined. We suggest that more sustained engagement with the local-level experience of empowerment may challenge assumptions about aims and objectives of empowering processes in development, and stand as a corrective to models of the empowered woman that may not acknowledge the extent to which empowerment is framed in, and by, social and relational dynamics and goals.

Keywords: women, empowerment, microcredit, Asia, Bangladesh, 'peace in the family'

\section{Introduction}

In Bangladesh, women's freedom of movement, choice, employment opportunities and access to decision-making processes and resources are shaped by social, political and economic institutions, practices and traditions that rest on male privilege (Sebstad \& Cohen, 2000). Women, particularly in rural areas, are often restricted to the home or household and play a primary role in the care of children and families (Parveen, 2007). It has been argued that the unequal distribution of power in rural Bangladesh should be challenged and equal rights for women established in every sector of society, including the household and family. In this context, the empowerment of women has been promoted as a 
potentially effective way of transforming gendered hierarchies of access, power and privilege. ${ }^{i}$ Over the past two and half decades, there has been tremendous growth of institutions in Bangladesh that administer microfinance, and the national government and donor agencies working in Bangladesh have encouraged the development of the microfinance sector, with the focus on alleviating poverty and empowering women.

Empowerment, as a strategy, process or desired outcome, has been argued to be key to the engagement of women in processes, policies and programs associated with international development. In this context, 'empowering women has become a frequently cited goal of development interventions' such as the provision of microcredit (Mosedale 2005, p. 243; see also Cornwall 2014, 2016). The nature and capacity of empowerment, however, continues to be ill-defined. Indeed, Cornwall (2016, p. 342) notes that empowerment has become 'one of the most elastic' terms in the practice and policy of international development with an 'expansive semantic range' (Cornwall 2010, p. 3), so much so that it has been labelled a 'buzzword' (see also Cornwall and Eade 2011; Batiwala 2007). ${ }^{\mathrm{ii}}$ In this sense, the evocation of empowerment runs the risk of adding 'glamour (rather than value) to interventions which actually seek to achieve a variety of economic and social outcomes which, though they may be extremely desirable in themselves, do not necessarily challenge existing patterns of power' (Mosedale 2005, p. 252). Further, many programs and projects that explicitly aim to empower women do not necessarily attempt to define what this means or how to assess whether these programs are a 'success' (Mosedale 2005, p. 243-4).
In this paper, we explore the intersection between microcredit and the empowerment of women in Bangladesh based on research conducted over a period of six months, from October 2013 until March 2014, in three villages Gabtoli, Sonatola and Sariakandhi - in Bogura District. Drawing on comments made by female members of microcredit programs run by Noble Education and Literacy Society (NELS), an NGO in Bangladesh, as well as their husbands and families, we critically assess core understandings of, and locally articulated 'pathways' to, empowerment. In these villages, empowerment is primarily talked about in terms of the Bengali concept of khomotayon, which is translated into English as 'empowerment' or, less frequently, shabolombi, which indicates self-sufficiency and independence. Women engaged in microcredit referred to local pathways of empowerment as an increased freedom of mobility, particularly outside of the house and surrounds; the capacity to make choices; and the ability to participate in major household decision-making processes, such as expensive purchases or other changes to houses, income and family events and structures. Women and men both argued that improvements in these fields of action for women indicated a level of empowerment that most supported or were able to reconcile with, particularly because they were ultimately about achieving 'peace in the family' - shonsaser shanti. Thus, avoiding 'chaos' (jhogra) in household relationships was an ideal that research participants sought to bring about through the medium of the loans, even if this did not happen as, in some cases, the loans became the source of conflict and family discord.

In the paper, we discuss key issues that arise in relation to empowerment and microcredit in the literature and then explicate the details and findings of the research conducted 
among microcredit households in the three Bogura villages described here. The paper then turns to the ways in which empowerment is framed in terms of attaining peace in the family, an ideal that underpins the language of empowerment among women involved in these village-based microcredit programs, their husbands or other men in their households. In conclusion, we suggest that there needs to be more sustained and critical engagement with the experience of empowerment from the perspective of women participating in microcredit programs, particularly in light of the connections drawn between microcredit and the empowerment of women in development policy and practice. Bringing to the fore local conditions, contexts and expectations, as well as the exploring the intricacies, capacities and constraints wrought by social and relational dynamics, can challenge assumptions about the ideal aims and objectives of empowering processes in development, as well as the role of microcredit in this process, in valuable and productive ways.

\section{Microcredit and Empowering Women}

Initial conceptions of empowerment in international development were shaped by feminist concerns with social justice, collective action and 'consciousness raising' (Cornwall 2016, p. 343; Mosedale 2005, p. 247). Feminists, activists and women's organisations from the Global South, seeking a way to articulate the exclusion or marginalization of women from many aspects of political and economic life, generated 'a clarion call for an approach focused on building women's capacity to mobilise collectively and demand rights and recognition' (Cornwall 2014, p. 130). In the 1980s and 1990s, empowerment was framed as a 'radical approach concerned with transferring power relations in favour of women's rights and greater equality between women and men' (Cornwall 2016, p. 343; see Batliwala 1993).

While this influenced the women in development (WID) approach to international development, WID also focused on the productive importance of women to economies and development processes and programs and sought to enhance women's access to both the opportunities and benefits of it. Much of the initial use of the term foregrounded economic and political empowerment, arising in a time of a growing interest in, and focus on, the individual, consumerism, and personal achievements as personal and social goals (Rowlands 1998, p. 11). Early notions of empowerment, thus, focused on women's access to power, bringing them into development processes and empowering them through enabling their participation in local political and economic structures and decision-making processes. The belief was that giving women living in poverty access to economic resources, such as credit, would lead to their overall empowerment, demonstrated by successful attempts to shift economic resources into women's hands, gain recognition for women's roles in household economies, and support women's leadership in local development (Batliwala \& Dhanraj 2007, p.21). It was based on the belief that if economic power and access to productive resources was directed towards women, hierarchical gendered roles and structures would be weakened, empowering poor women to enact and bring about change (Batliwala \& Dhanraj 2007, p. 22).

Definitions and understandings of empowerment have been challenged and transformed over the years to embrace key questions about the nature and experience of empowerment, with a focus on exploring the needs and 
desires of different women in diverse places. The focus on the transformation of an individual and her own particular circumstances, has also been critically engaged, along with the debate about the extent to which empowerment targeted at individuals may undermine communal goals and activities, or that empowered women are not necessarily those who can, or wish to, draw distinctions between personal and familial needs (Afshar 1998, pp. 1-2). From the late 1990s, there was a proliferation of studies that focused on measuring or defining power and empowerment, making constructive comparisons in different contexts and places, or presenting examples of specific instances of empowerment in women's lives (Kabeer 1999, p. 436). In this literature, empowerment is often imagined as a dynamic process of self-consciousness leading to decision-making power and ultimately changes in a person's ability or capacity to act and interact in social settings (Karl, 1995). Kabeer (1999, p. 435), for instance, argued that empowerment is a process by which people who had been unable to 'make strategic life choices' acquire that ability, going from a state of disempowerment to empowerment. In this process, power is understood as the ability to make genuine choices and to be disempowered implies a denial of choice (see also Kishore and Gupta 2004). ${ }^{\text {iii }}$ From her work among women's groups in Honduras in the 1990s, Rowlands (1998, pp. 22-23) identified three ways in which empowerment was experienced by women she worked with: at a personal level - from a confidence to move around, to move into positions of power in the community or workplace; as collective empowerment through which women reported feeling empowered by participation in collective activities, in the ways in which they were organised or the activities they were involved in; and many women also reported feeling a sense of empowerment in close relationships, including with husbands, parents, and mothersin-law. She writes:

In this example, there are many instances of women increasing their ability to act, to perceive themselves as capable, to hold opinions, to use time effectively, to control resources, to interact with others, to initiate activities, to respond to events, and so on. These instances of increased power to, power with, power from within and, on occasion, power over are significant (Rowlands 1998, p. 23).

In this kind of perspective, empowerment is 'an unfolding iterative process' concerned primarily with changing power relations (Cornwall 2016, p. 344). Similarly, Mosedale (2005) explores a model of power through which to assess empowerment processes and effects, based on notions and practices associated with 'power over', 'power within', 'power with' and 'power to'. In this model, power is fluid and complex and includes 'structural faultlines' that are predicated on class and sex, and membership in a group or category of people that 'has significant implications for the shape of the power structure in which an individual operates', and constrains or creates boundaries against which individuals seek to change or, alternatively, accept (Mosedale 2005, p. 251). 'The extent to which an individual presses against, or accepts, these boundaries and the extent to which change is opposed (and the power of those opposing it) all contribute to the shape and durability of these boundaries' (Mosedale 2005, p. 251). Mosedale points to the context or situation in which people act and the extent to which they may be powerful in one environment and less so in others. For her, empowerment is a process through which gender roles are challenged and 
transformed 'in ways which extend their possibilities for being and doing' (Mosedale 2005, p. 252).

In the 2000s, empowerment took on a different emphasis from women's rights and collective action to development interventions focused on girls and women and, later, men and masculinities (Cornwall 2014, p. 13). Investing in women and girls, in particular, became a question of 'smart economics' as they were assumed to be 'responsible and reliable' and thereby a 'safer bet' for investment (Cornwall 2014, p. 131). In this sense, the focus of empowerment has changed from shifting existing power inequalities and consciousness-raising, to the provision of resources, assets or services: the assumption being that once women have access to these, they will be able to make changes across their lives (Cornwall 2016, p. 356). 'Such investments are presented as straightforward transactions, a matter of putting directly into the hands of women and girls, training them in the arts of the market, and watching them flourish as they lift their families, communities and national economies' (Cornwall 2014, p. 131).

In this context, one of the key questions is whether empowerment in one field of action leads necessarily to empowerment in (all) other domains of life. In terms of microcredit, for example, it has been questioned whether making credit available to women living in poverty brings about a totalising process of empowerment in all aspects of their lives. Sengupta (2013, p. 292) notes that microcredit has been perceived as a 'magic bullet' that 'empowers women members through economic self-sufficiency' in terms of a variety of capabilities and opportunities, such as income generation and better food security, access to education and health, and visibility or mobility. Thus, microcredit has often been articulated as a pathway to the empowerment of women, as well as vehicle for poverty alleviation more generally. ${ }^{\text {iv }}$ These programs have been largely focused on poor women, in particular, and based on lending small amounts of money to women organized into groups - thus relying on 'group liability to ensure loan repayment' usually repaid through weekly installments (Kabeer 2001, p. 63). While debate continues about the effectiveness of such credit programs in the reduction or alleviation of poverty, increasingly they have become a platform for women's empowerment (Kabeer 2001, p. 63) and by the early 2000s, microfinance was linked clearly with empowerment in a more general sense. But, as Mosedale (2005, p. 247) notes, there has been a great deal of debate concerning the effectiveness of this as a strategy for empowering women, with both negative and positive evaluations of the impact and effect of microcredit (Kabeer 2001, p. 63). Many have argued that economic improvement in women's lives does not necessarily correlate with empowerment in a wider sense, particularly when understood in terms of the ability to undertake collective action, bring about change, or generate choice, opportunity and awareness (Mosedale 2005, p. 248).

Debates have been framed in terms of a variety of issues: including who maintains managerial control over the loans, the status and influence associated with access to credit, increased awareness of legal and political rights and opportunities for women, the impact on levels and incidence of family and domestic violence, the development of greater financial capacity and achievement, the possibility of the empowerment of women through working in groups on common goals, and increased levels of mobility and autonomy for women. It has also been suggested that microcredit programs may have indirect rather 
than direct effects on women's empowerment (see Ashraf, Karlan \& Yin 2010). Zaman (2001), for example, reports that microcredit plays a significant role in reducing the vulnerability of poor men and women in general through asset creation, income and provision of emergency assistance. Women's access to microcredit may also facilitate purchasing power as well as increased political \& legal awareness and appears to be associated with an overall reduction in the incidence of violence against women in some contexts (Hashemi, Schuler \& Riley, 1996; Kabeer 2001). Malik and Luqman (2005) note that offering microcredit to women may enhance their economic status and enable them to earn extra income through which they can gain greater financial autonomy. Amin, Li and Ahmed (1996) point to increased levels of mobility, the positive exposure of women to outside influences and experiences, and access to up-to-date information by attending group meetings and training sessions, all of which may increase the economic status of women and ultimately lead to their empowerment. Hashemi et al (1996, p. 636) argue that even minimalist credit programs empower women through 'strengthening their economic roles, increasing their ability to contribute to their families' support, and that they also empower women through other mechanisms'.

At the same time, there appear to be instances in which microcredit programs, for example, have served to maintain the lower status of women borrowers (Obaydullah, 2000). And, it has been argued that, without control over the loan or the ability to make or participate in major decisions-making processes in a family or household, women cannot be empowered simply by attending group meetings and making weekly repayments (Norman, 1997). Goetz and Sen Gupta (1996, p. 45), in their assessment of the management of microcredit loans in Bangladesh (including villages in Bogura District), explore the extent to which women retain control over the loan - finding that 'a significant proportion of women's loans are directly invested by their male relatives, while women borrowers bear the liability for repayment'. Goetz and Sen Gupta (1996, p. 49) noted that $63 \%$ of the women fell into the categories of partial, very limited or no control over the loans 'indicating a fairly significant pattern of loss of direct control over credit'. In this context, Sengupta (2013, p. 280) argues that in the 'triad of poverty, empowerment and microfinance', the latter operates as a 'coping strategy for poor people' particularly operating in a neoliberal economy, in which women are under the most pressure to ensure survival but without benefits such as increased rights or entitlements. At the same time, she argues, women's rights-based groups have the capacity to subvert the neoliberal agenda in which poverty and empowerment are individuated, and use credit 'as an additional tool or as an entry point to building larger collectives and programs that strengthen women's bargaining power as both economic and social actors' (Sengupta 2013, p. 289). Yet, microfinance, alone, offers little more than a new financial tool, and even if livelihoods and income are generated, gender relations in families and households or other forms of hierarchical structures and practices are not necessarily transformed. On the basis of this, Sengupta (2013, p. 297) writes; 'even in the case of best practices, microfinance alone can achieve little with regard to poverty or women's empowerment'. 
In the following sections, we explore the ways in which women in Bogura Distict, Bangladesh, participate in microcredit programs and how they understand and rationalize the impact on their lives and that of their families and relationships. We critically assess the terms in which these women, their husbands and other male kin, and wider community members employ the term 'empowerment' in the context of engagement with these loans and the kinds of empowering pathways open to them. We also point to the significance of the social and relational nature of empowerment and its implications for the management of microcredit loans and involvement in programs, as well as the commonly held goal of 'peace in the family'.

\section{Women, Empowerment and Microcredit in Bogura District}

This research was carried out in three villages of Bogura district, Gabtoli, Sonatola and Sariakandhi, over a sixmonth period. Bogura is one of the northern districts of Rajshahi Division of Bangladesh. It became a district in 1821 and is comprised of 12 sub-districts. The village of Gabtoli was established in 1917: the largest village of the study, it had 290, 190 inhabitants in 2001. In 2011, there were 1334 people (per sq. $\mathrm{km}$ ) with a total of 83,411 households. Sonatola came into existence on January, 1981 and in 2001, there were 167, 547 inhabitants with 1191 people (per sq. $\mathrm{km}$ ) in 2011. As the oldest village, Sariakandhi was established in 1886 and, in 2001, there was a total population of 240,083 inhabitants with a density of in 2011 was 663 people (per sq. $\mathrm{km}$ ).

56 (male $=28$; female $=28$ ) participants from these villages were interviewed, another 40 female participated in focus group discussions, and 2 male NELS field officials were also interviewed. Participant observation was used to gain another level of research data about daily life in the village for those involved in microcredit programs. The research was based on active members of NELS' microcredit program and male household members, primarily husbands, father-in-law or fathers or even brothers of these women between the ages of 18 and 50 years of age. ${ }^{\mathrm{v}}$ NELS started its operation in January 1993 and is one of the NGOs working in Bogura disbursing microcredit loans. With the head office located in Gabtoli, Bogura, it limits its services to Bogura district. In 2013-4 during the period of field research, NELS consisted of eight staff who covered 34 villages in Bogura district. Over one thousand and one hundred women were listed as beneficiaries of these loans at the time, the majority of whom received loans as a group, with a total of fifty-four groups of women. NELS provided group-based loans focusing on group savings with the condition that a male household member stood guarantor for each loan. In 2013-4, NELS had disbursed 305, 75,000 BDT, representing itself as engaged in income generation for poor families in the region, and had gained considerable experience in working with community-based organizations. There were other NGOs working in the area, namely BRAC, TMSS, ASA and GUK, who offered similar microcredit programs to those of NELS but it was noted by NELS members that they paid a lower rate of service charge than others, had to meet less installments on the loans, and the loans were comparatively easily and generally approved quickly (usually within seven days). There was also a level of flexibility in the repayment of NELS loans, additional loans could be approved before the original loan was fully reimbursed and, finally, outstanding loans were waived for members (or guarantors) who died before the loan was reimbursed. 
Kabeer (1999, p. 64) notes that the image of the empowered woman underpins credit interventions in Bangladesh (see also Ackerly 1995, p. 56), but strategies for achieving women's empowerment vary from individual to individual and between organisations. The primary focus of NELS at the village level seemed to be largely understood in terms of providing loans and recover the costs of these loans from borrowers: the empowerment of women was not explicitly articulated as a goal of providing loans to women in these villages. The NELS officials interviewed admitted that they had never been engaged in discussions about empowerment or asked to define strategies to achieve it. One, however, suggested that;

We can achieve women's empowerment by providing microcredit loans. If women members utilize their money in proper way then they can easily have extra money after paying back our installments. We also need to monitor their activities as well. When a woman gets return from her investment or if her husband benefits from her loans, then she is honored in her family and that's how she can be empowered. However, we need close supervision and monitor their activities and need to ensure that women members' husbands are using the loans in proper way and if needed, we can provide suggestions in this regard. According to our policy, if a woman pays back her loan successfully, then we usually increase the amount of money for her next loan. In this way, she can continuously be benefitted from microcredit loans and her socio-economic status will be increased and she will ultimately be empowered.

During the field research, each participant was asked what they understood by the term empowerment. Although most of them had heard of the word, many had differing understandings of what this term referred to and it was described variously as self-sufficiency, gaining power, and accessing women's rights. The majority of women expressed feeling empowered through an increased level of freedom of movement, the ability to make a range of choices and take action based on them, and being able and/or invited to participate in major household decisionmaking processes. These changes were identified as essential to being considered an empowered woman. Most of the women argued that being free to move around outside the house was very important to feeling empowered. After joining microcredit programs, a greater level of freedom of movement outside of the house and its surrounds signified a level of independence and self-sufficiency, which many referred to as empowerment. When asked 'do you think that you are empowered by taking out NELS's loans? If so, how?' one of the women, a participant of a focus group, replied:

I think we are empowered. After becoming a NELS's member, my husband's attitude towards me, and I think other members' husbands too, has completely changed. I am now free to attend group meeting and free to go to NGO's office. Before joining NELS, my husband did not like me going out. Now, you see, not only me, many women are coming outside of their houses to attend group meetings and we can share our family and social issues with each other.

Another woman pointed to mobility as emblematic of empowerment:

Women's empowerment is women's freedom of mobility. If we can move freely then we will be empowered. There are lot of constraints from our families and society in our free movement. When all of our family members, especially our 
husbands and the society, will accept our freedom of movement, then women's empowerment will take place.

At the same time, the women concurred that this freedom to move around outside of the home was not universally applicable or accepted. In an individual interview, a female microcredit member commented;

I think my family acknowledges women's freedom. I can move freely and attend NGO's meeting and group meetings. My husband does not prohibit me from attending these meetings and he, at first, even encouraged me to join microcredit programs. My husband knows the meeting schedule and I don't have to ask him for attending these meeting. But not every wife in our village enjoys the same freedom. Some husbands are very conservative and they don't allow their wives going outside of their home. So, I think every family does not accept women's freedom, especially their freedom of mobility.

Some women asked their husbands to accompany them when they left their houses. One woman said, 'I don't want any chaos in my family, I usually ask my husband before going anywhere, even attending a group meeting.' In focus groups discussions, women also noted that they kept their husbands informed of their movements; "we usually inform our husbands before going anywhere. Most of us can move freely in our village after informing them'.

Most of the women pointed to the freedom and ability to make choices as also significant in feeling empowered, including the freedom of choice to join (or quit) microcredit programs. Some of the responses from women in focus group discussions indicated that they, or others they knew of, were not given that level of choice in terms of joining NELS microcredit programs:

We have been taking loans from NELS for many years. Our economic condition is better now. Having observed our improvement, many other women are also interested to join NELS, but they cannot due to their husbands. Their husbands do not like NGOs' activity and microcredit loans. We personally know many women who are very keen to do something by their own with NGO's loan but they cannot do it because of their husbands' negative attitude towards NGOs. Most of the women's [right to] choose [holds] no value in our villages, especially to their husbands.

It was noted that women's capacity to participate in microcredit programs was often contingent on their husbands' perceptions of these programs. In this context, some women who were interested in taking out loans were unable to join the credit programs without the support of their husband or family. ${ }^{\mathrm{vi}}$ In this context, one woman interviewed in our study argued that changes in this domain were very significant:

In our villages, very few women are respected. Most of them are neglected in their family and in the society. They have no say in their families. In that situation, if a woman's decision is given importance, and she is welcome to share her opinion in any major decision-making processes in her family, then I think she is empowered.

In terms of making major decisions in the family or household, it was found that few women were invited to take part in making major decisions and their opinions or preferences were not often accepted by male members of the household. Despite this, many of the women said that they were content making minor household decisions. In individual 
interviews, both men and women spoke about this in terms of appropriate and effective gendered roles in marriage and the household. Some women, for instance, thought that it was better if their husbands made the major decisions, given their experience and expertise in these domains.

My husband earns for my family. He works hard to feed us and he will always do well for us. If he thinks that something needs to be done for the betterment of our family, he does that and I have full faith in him. Sometimes, if he intends to share with me, then I give my opinion on that particular matter. I have one son and I am mainly busy with him and my household jobs. My husband is responsible to maintain outdoor works and responsibilities.

One man acknowledged that his wife did not like to be involved in making major decisions for the family, saying 'previously, when I used to ask her about anything and to give her opinion, she told me that she did not know which one will be good for the family...But in major decision-making, she does not like to be involved and that's why I don't ask her any more'.

Each woman interviewed indicated satisfaction with the terms and conditions of the loans they had received from NELS, including the utilization or management of loans by their husbands or other members of the household in the instances in which this had occurred. Although there was a noticeable number of women who reported not being involved in making major decisions in the family, the majority considered themselves empowered by the relative ease which they could move outside of the house - even if this consisted primarily or only of going to NELS' offices and attending group meetings. In addition, most of the women participated in minor decision-making processes such as the purchase of daily necessary goods like, rice, oil, soap, and fish.

\section{Peace in the Family: Social and Relational Aspects of Empowerment}

Empowerment is a term that both women and men in this study engaged with and experienced in a variety of different ways and contexts. The social and relational aspects of empowerment, however, were repeatedly articulated as central to the ideal, process and lived experience of empowerment by the women holding the loans and the men in their households. As Cornwall (2016, p. 344) argues, 'any account of the lived experience of empowerment and disempowerment must embrace the essential sociality of the concept' as women's daily lives are embedded in webs of relationships that shape how they 'manage the relational as well as economic contingencies that arise' (Cornwall 2007, p. 29). Cornwall (2007, p. 43) points to the ways in which affective relations also 'play a significant part in women's pathways of empowerment', whether relationships with men, children or other women (see also Kabeer 1998). Focusing on these relations, she writes, aids in shifting the focus, away from the individual to the intersubjective and relational dimensions of women's agency in the various domains of association in which women live their lives: their homes, their workplaces, their places of workshop, the places where they socialize and have fun. Rather than extracting women from the webs of sociality in which they live their lives, this figures the other people in their lives - their husbands, lovers, friends, mothers, sisters, colleagues - into the picture (Cornwall 2007, p. 43).

Shifting the focus to primary relationships in women's lives allows for the development of a deeper understanding of 
women's actions and motivations, whether a level of ambivalence about the extent to which they desire to move freely outside the home without being accompanied by, seeking permission from, or informing their husbands of, their movements or participating in making major decisions in the household or family. Kabeer $(2001$, p. 72) noted a similar characteristic in her analysis of the Small Enterprise Development Project (SEDP) in Faridpur and Mymmensingh Districts, Bangladesh, reporting that $40-50 \%$ of women holding loans reported joint-decision-making processes with their husbands and saw it as irrelevant that the loan had been granted in their name. This reflected a 'taken-for-granted jointness' of household interests and as well as an awareness of their reliance on male householders for the implementation of the loan (Kabeer 2001, p. 73).

In Bogura District, many of the women saw empowerment in terms of the development of the self-sufficient family or household, brought about by the positive impact of a loan on the family's economic situation.

Empowerment is something through which we can be self-sufficient. When we have an income source and can spend money for the family then we are empowered. I think I am empowered because I am taking out loans and handing these over to my husband. I am helping my husband and my family. I think I am self-sufficient and empowered with the help of the NGO's loans.

For some of the women, empowerment implied a wider social and structural transformation than that of family or household. Many participants in focus group discussions agreed that an important aspect of empowerment was challenging gender hierarchies and inequalities;
We are discriminated in every sector in the society and even in our families. We are discriminated in education, in the job sector and even in property distribution. To achieve women's empowerment, we need to eliminate or minimize gender discrimination.

When questions were asked about the wider acceptance of changes in women's lives and an increased access to opportunities brought about by NELS loans, participants argued that women's freedom of movement and participation in major decision-making processes was not unilaterally accepted by families or other villagers. ${ }^{\text {vii }}$ In focus group discussions and individual interviews, it became evident that women's ability to move around freely outside of the home and play a primary role in making major decisions regarding household purchases and activities was dependent to an extent on the types of family arrangements in which they lived. Women living with their husbands, parents-in-law and/or extended families had comparatively less freedom to move around outside of the home, except perhaps activities associated with the loans. Women living with their husbands and children in houses separate from extended kin were more likely to participate in major household decision-making processes. Women in this latter kind of household said that they felt they needed independent income sources to aid in the maintenance of the household, and some of these managed their own loans and operated grocery shops adjacent to their houses, nurtured goats or performed handicraft jobs within their homes. These women were more interested in being involved in incomegenerating activities that did not require them to operate outside of their home, something that Kabeer (2001, p. 69) noted also for SEDP participants, where women with SEDP loans sought to establish home-based activities that allowed them to work 
without being in places that made them visible and vulnerable to social approbation.

For women in Bogura, the level of education also had an impact on women's freedom to move beyond the house and be a key participant in making major household decisions. Those research participants who had completed high school, for example, had more freedom of movement than others. It was also noted that the gender of a woman's children was a factor in her being invited to be involved in major decisionmaking processes in the family as women who had sons, for example, were invited to participate in household decisionmaking more often than those who had only given birth to daughters. Conversely, it was observed that differing forms of religious belief and practice did not seem to have an appreciable or at least overt impact on women's ability to move around outside of the home: Muslims and Hindu women alike pointed to the need to seek approval from male household members before moving outside of their home, except to visit the office or for group meetings with other women. Kabeer (2001, p. 69) has pointed to the significant role of and adherence to 'purdah norms' that limit women's public mobility, the choices they make in terms of the kinds of enterprises to establish with the loan money, as well the ability to participate in market-based activities and transactions in Bangladesh. She notes that for women involved with the SEDP, private and public domains were not clearly demarcated but seen as a "continuum of locations in the public domain, ranging from acceptable to unacceptable places for women to be seen' in which the local neighbourhood and SEDP offices were seen to be acceptable places to be seen while rural markets were not (Kabeer 2001, p. 69). In Bogura, women also felt that they could not interact or engage in transactions in certain spaces like the marketplace; or, even, in the context of selling milk to a male customer in the household space.

Affective relations were significant in determining how and why women applied for loans as well as managed, or relinquished control over, the loans. When asked why they ceded control over the management of their loans to their husbands, several women suggested that they acknowledged that their husbands were more capable and experienced in terms of dealing with money and markets, as they were the ones who performed 'hard work' outside of the home and that they were the primary 'earning member' of their family. Some pointed out that their husbands spent their days pulling rickshaws and working in brick fields, and these jobs were difficult and physically challenging. In this context, women encouraged their husbands to use the money from the loans to find different work or alternative opportunities. Through such a process, women talked about how empowered they felt - the result of their financial contribution to their families and its acknowledgement in terms of status, freedoms and access to opportunities and decision-making processes. Kabeer (2001, p. 71) notes a similar finding among women taking out SEDP loans, who reported a heightened sense of achievement and selfworth through their contribution to the family and household. At the same time, they also expressed a commitment to the "wellbeing and dignity of the work engaged in by other household members', so much so that they highly valued the capacity to aid husbands to get out of demeaning economic relationships and positions with money from the loans.

On the other hand, a significant minority of the women in Bogura District said that they felt dependent on their husbands 
or other male household members and felt obliged, or were forced, to allow them to manage the loans. It was noted, however, that this arrangement sometimes resulted in conflict in the family and was often a primary reason for women dropping out of the microcredit program. ${ }^{\text {viii }}$ Repayments were often a factor, as late repayments or, alternatively, no repayments, were common in those kinds of situations. The influence or direct control of male household members was also evident in the 'choice' to apply for loans. Several of the women noted that they had been encouraged, if not forced, by their husbands to join NELS and obtain credit, a situation that resulted in these women became increasingly financially dependent to their husbands.

Most women felt that ceding the management of the loan, either voluntarily or as a result of force or persuasion, was central to developing and maintaining good family relations, and avoiding conflict in their marriages. Indeed, using loans partially or completely for relational projects or purchases, or giving control of the loans to male household members, was seen to be key to achieving a primary goal - peace and happiness in the family. The ideal of 'peace in the family' (shonsaser shanti) was a common theme in interviews and focus groups discussions and microcredit was perceived as an important pathway for the achievement of peace in a marriage, family or household. One woman argued that being empowered or self-sufficient - shabolombi - was key to achieving 'peace in the family'. She said; 'we can achieve this by becoming microcredit members so that we can provide economic assistance to our family. Women providing financial support to her family can also help maintaining peace and harmony in that family'. Another woman stated;
In our society, it is a cherished desire for every woman that after getting married, she will have a peaceful family and will be happy with her husband and children. Peace in the family is very important to maintain a healthy life as well. Because there are some families in our society who are having chaos among husband and wife and going through a stressful life. This also affects children's lives.

A man also noted during his interview the importance of peace in the family for raising children:

To maintain a family successfully and raise the children, peace in the family is very important. I believe that women's role is very important in our family and we should acknowledge that. By sharing family tasks and acknowledging each other's roles, we can bring peace in the family.

Another man stated that he really appreciated the contribution his wife had made to his family. 'It helps me a lot in maintaining a healthy family life. I am happy with my wife and maintaining a peaceful family life; and I think by mutual understanding and respect between husband and wife, we can achieve a peaceful family life'. Similarly, one of the women involved in microcredit said; 'of course I want peace in my family and I think this can be achieved by sharing any family decision with each other and implement the decision with the consent of both the husband and wife of the family'. Kabeer (2001, p. 72) reported a similar focus on taking out SEDP loans as a means of creating more harmonious family and marital relationships. Many of the women pointed to improvements in the quality of these key relationships: as they became less dependent on their husbands, the stress and frustration associated with providing for the household felt by men was 
lessened. 'The result was a reduction in levels of tension and conflict and greater affection from their husbands' (Kabeer 2001, p. 72).

\section{Conclusions}

While empowerment remains ill-defined, cast as a primary goal or, simultaneously, a means for bringing about more effective development programs, the idea of empowering women remains a primary imaginary in development practice and policy. As Cornwall (2011, p. 1) reflects: 'Words make worlds. The language of development defines worlds-in-the-making, animating and justifying intervention in currently existing worlds with fulsome promises of the possible'. While empowerment may offer many a 'fulsome' promise, key insights from the literature and research on empowerment point to the realization that empowerment is a process rather than a 'fixed state' or 'endpoint', and cannot easily be measured or quantified. Mosedale (2005, p. 244) suggests that neither women or men 'arrive at a stage of being empowered in any absolute sense. People are empowered or disempowered, relative to others or, importantly, relative to themselves at a previous time': thus, empowerment is relative, shifting and subjective. Empowerment is imbricated with shifting power relations and structures, power being part of the social environment in which people strive to make choices. In this context, social boundaries, norms and expectations about gendered behaviour serve to constrain potential choices, which limits potential fields of action for everyone, not simply for women. Constraint on action does not necessarily indicate disempowerment, however, as everybody is constrained to some extent, but it does mean that disempowerment needs to be assessed through the ways in which these constraints impede the pursuits of interests relative to others (Jakimow 2006, p. 3). Thus, measuring empowerment is complicated by the necessity to identify people's interests without taking away from their relative agency to make their own decisions (Jakimow 2006, p. 3) and must occur, be understood and measured in relation to local conditions.

Empowerment is also fundamentally social and relational (Cornwall 2016, p. 344). As discussed in this paper, in Bogura District, microcredit and empowerment are perceived and experienced as means through which women and men seek to attain peace in the family - a state in which men and women can raise their children with a level of security, health and wellbeing. In this process, loans provide a level of economic security that is seen to (potentially) lead to self-sufficiency and independence, associated with empowerment. This, in turn, aids in the maintenance of a 'peaceful family' - in which husband and wife work together to maintain the household economy and family over time. In this conception, empowerment is a means to achieve the ideal of the peaceful family. Microcredit appears largely instrumental in this perceptive model - providing the means by which families work to create a situation in which they can be harmonious, secure and self-sufficient. At the same time, being a member of NELS provides more than simply access to credit - it also aids in a level of freedom of movement, some impact on the capacity to make choices, potentially taking an active role in making important decisions in the household as well as being engaged in training programs and group work with other women. Attendance at activities associated with NELS, such as group meetings, was seen as a factor through which the women 
felt empowered. This has been noted elsewhere, including India, where 'some of the empowering aspects came from women members' presence and participation in various programs organized by the study NGO including group meetings' (Goetz and Sen Gupta, 2013, p. 295).

Yet these experiences and perceptions of empowerment are complex, often transitory and difficult to measure. As Cornwall (2016, p. 344). suggests, empowerment can be temporary, and some opportunities may lead to disempowerment rather than empowerment as "what empowers one woman might not empower another: there is no one-sizefits-all recipes for empowerment'. Neither does empowerment in one aspect of a woman's life lead to empowerment in all or other parts of her life. Cornwall (2016, p. 345) points to importance of seeing the process of empowerment in metaphorical terms - such as a

journey travelled along pathways, one on which women can travel alone or in the company of others, through terrain that may be pitted with thorny thickets, fast-flowing rivers, mud and marshes, and song paths that can double-back on themselves, meander on winding side-routes and lead to dead-ends, as well as opening up new vistas, expanding horizons and extending possibilities.

Drawing on the metaphor of empowerment as a journey for which there are many pathways is important here, as it encapsulates specific economic, historical, political and sociocultural moments, practices and contexts. It also encourages a holistic and critical analysis of sites and dynamics of empowerment that 'aims to understand the relational dynamics of power and positive change in a variety of levels, in different spaces and over time' (Cornwall, 2016, p. 345). In this kind of approach, microcredit provides one of several pathways, which offers certain kinds of resources, effects and opportunities and acts as a base for 'empowering actions' that may remove a level of constraint on people's capacity to act (Jakimow 2006, p. 3). At the same time, as Kabeer (2001, p. 83 ) suggests, there are a variety of reasons for offering loans to women; and the 'fact that women are more likely to share their loans with male household members than men are with women, in my view, merely strengthens the argument for lending to women'. Goetz and Sen Gupta (1999, p. 47) argue similarly that, whatever the rationale for targeting women in microcredit programs, the increase in availability of credit to women living in poverty in Bangladesh 'must be seen as a positive contribution to efforts to challenge gendered terms of access to productive resources and opportunities', given the tremendous reach and impact of credit programs and the 'tight sociocultural constraints on women's market access and on their freedoms and capacities to shift significantly their rate of market engagement in Bangladesh'. Thus, both empowerment and microcredit can be enabling and positive aspects of development programs, as distinct experiences and practices as well as when these are 'talked together' in policy and practice. We argue, however, that a focus on localized notions and experiences of empowerment and microcredit can aid in challenging assumptions about empowering processes and key outcomes in development, and stand as an important corrective to models of the empowered woman that may not acknowledge the extent to which empowerment is framed in terms of social and relational dynamics and goals.

To better understand whether any other factors other than accessing microcredit benefit reasoning peace and happiness in 
the families, the authors suggest further study focusing on microcredit members of both rural and urban areas. Further study focusing on the same might also be conducted comparing two or more MFIs (Micro Finance Institutions) to find out whether any other factors like, their (microcredit members) educational qualification, family status in the society and religious background have any impact on women's empowerment. Due to time constraint, the study was conducted focusing only on microcredit members in Bogura district, Bangladesh. The study might also be carried out comprising both members and non-members of microcredit programs in other districts of Bangladesh to ensure the impact of the program on its members to bring about a change in their families through empowering them.

\section{References}

1. Ackerly, B. A., "Testing the tools of development: Credit programmes, loan involvement, and women's empowerment" in IDS Bulletin, Vol. 26 (3), 1995, Brighton, England : Institute of Development Studies- 1985, University of Sussex, pp. 56-68.

2. Afshar, H., 'Introduction: Women and Empowerment - some illustrative studies' in Haleh Afshar (ed.), Women and Empowerment: Illustrations from the Third World, (Houndmills, Basingstoke, Hampshire and London: Macmillan Press, 1998), pp. 1-10.

3. Amin, R., Li, Y., and Ahmed, A.U., "Women's credit programs and family planning in rural Bangladesh" in International Family Planning Perspectives, Vol. 22 (4), 1996, Guttmacher Institute, United States, pp. 158-162.

4. Ashraf, N., Karlan, D., and Yin, W., "Female empowerment: Impact of a commitment savings product in the Philippines" in
World Development, 38 (3), 2010, Elsevier, Amsterdam, Netherlands, pp. 333-344.

5. Batliwala, S., Empowerment of Women in South Asia: Concepts and Practices, (1993), New Delhi, India : FFHC/AD Programme Officer.

6. Batliwala, S. and Dhanraj, D., "Gender myths that instrumentalise women: a view from the Indian front line", in Feminisms in Development: Contradictions, Contestations and Challenges (London and New York: Zed Books, 2007), p. 21.

7. Cornwall, A., "Of choice, chance and contingency: 'Career strategies and tactics for survival among Yoruba women traders" in Social Anthropology 15(1), 2007, Cambridge University Press, England, pp. 27-46.

8. Cornwall, A., 'Introductory Overview - buzzwords and fuzzwords: deconstructing development discourse' in Andrea Cornwall and Deborah Eade (eds.), Deconstructing Development Discourse: Buzzwords and Fuzzwords, (2011) Warwickshire, UK: Practical Action Publishing \& Oxfam, pp. 1-18.

9. Cornwall, A., "Taking off international development's straightjacket of gender" in The Brown Journal of World Affairs, 21(1), 2014, Watson Institute for International and Public Affairs, Brown University, US, pp. 127-139.

10. Cornwall, A., "Women's Empowerment: what works?" in Journal of International Development, 28(3), 2016, John Wiley \& Sons, United States, pp. 342-359.

11. Cornwall, A. and Eade, D., (eds), Deconstructing Development Discourse: Buzzwords and Fuzzwords (2011), Practical Action Publishing \& Oxfam. Warwickshire, UK.

12. Goetz, A., and Sen Gupta, R., "Who takes the credit? Gender, power and control over loan use in rural credit programs in Bangladesh" in World Development 24(1), 1996, Elsevier, Amsterdam, Netherlands, pp. 45-63. 
13. Hashemi, S. M., Schuler, S. R., and Riley, A. P. "Rural credit programs and women's empowerment in Bangladesh" in World Development, 24 (4), 1996, Elsevier, Amsterdam, Netherlands, pp. 635-653.

14. Hoque, M., and Itohara, Y., "Women empowerment through participation in microcredit program: A case study from Bangladesh" Journal of Social Sciences, 5 (3), 2009, Science Publications, New York, US, pp. 244-250.

15. Jakimow, T., "Empowering Women in India: A Critique of the SHG Blueprint in India" Participatory Development Working Papers No 06/02 September, 2006, The Australian National University, Canberra, Australia.

16. Kabeer, N. (1998). Money can't buy me love? Re-evaluation gender, credit and empowerment in rural Bangladesh. IDS Discussion Paper 363, 1998, Brighton, England: Institute of Development Studies- 1985, University of Sussex.

17. Kabeer, N., "Resources, Agency, Achievements: Reflections on the Measurement of Women's Empowerment" in Development and Change, 30 (3), 1999, Wiley-Blackwell, New Jersey, United States, pp. 435-464.

18. Kabeer, N., "Conflicts over Credit: re-evaluating the empowerment potential of loans to women in rural Bangladesh" in World Development. 29. (1), 2001, Elsevier, Amsterdam, Netherlands, pp. 63-84.

19. Karl, M., "Book Reviews" in Development in Practice, 5 (4), 1995, Taylor \& Francis Group, UK, pp. 370-374.

20. Khatun, M. A., Islam, M. A., and Majumder, S., "Why some poor women in Bangladesh do not opt for micro-credit'?" in Journal of Bangladesh Agricultural University, 11 (2), 2013, The Bangladesh Agricultural University Research System (BAURES), Bangladesh Agricultural University, pp. 285-292.
21. Kishore, S., and Gupta, K., "Women's empowerment in India and its states: Evidence from the NFHS" in Economic and Political Weekly, 39 (7), 2004, Sameeksha Trust, India, pp. 694-712.

22. Mahmood, S.A. I., "HIV/AIDS: Socioeconomic impact on w omen", The Independent, Dhaka, 2004, December 24.

23. Malik, N. H., and Luqman, M., "Impact of microcredit on women's empowerment" in Pakistan Journal of Agricultural Sciences, 42 (3\&4), 2005, The Pakistan Association of Advancement in Agricultural Sciences (PAKJAS), Faisalabad, Pakistan, pp. 100-105.

24. Mosedale, S., “Assessing women's empowerment: towards a conceptual framework" in Journal of International Development, 17 (2), 2005, John Wiley \& Sons Ltd, pp. 243-257.

25. Norman, M. The role of microcredit in poverty reduction and promoting gender equity: A discussion paper (1997), Ottawa, Canada: Canadian International Developmental Agency (CIDA). Retrieved from http://gadguatemala.weebly.com/uploads/3/7/5/2/ 3752316/microcredit and gender equity.pdf

26. Obaydullah, M. A., Measuring the success of microcredit. Bangladesh Observer, Dhaka, 2000, August 7.

27. Parveen, S., "Gender awareness of rural women in Bangladesh" in Journal of International Women's Studies, 9 (1), 2007, Bridgewater State College, Massachusetts, United States, pp. 253-269.

28. Rowlands, J., A word of the times, but what does it mean? Empowerment in the discourse and practice of development, in Afshar, H. (ed), Women and Empowerment: Illustrations from the Third World (1998), Macmillan Press: Houndmills, Basingstoke, Hampshire and London, pp. 11-34.

29. Sebstad, J., and Cohen, M. Microfinance, risk management and policy (2000), AIMS Paper, Washington: D.C, Management Systems International. 
30. Sengupta, N. "Poor women's empowerment: The discursive space of microfinance" in Indian Journal of Gender Studies, 20 (2), 2013, SAGE Publishing, India, pp. 279-304.

31. Zaman, H., Assessing the poverty and vulnerability impact of microcredit in Bangladesh: a case study of Bangladesh Rural Advancement Committee (BRAC). Background paper for the World Development Report (WDR) 2000/2001, Washington, D.C: The World Bank.

i After independence in 1971, the Bangladesh government became concerned about violence against women and enacted several laws, such as the Dowry Prohibition Act 1980, and the Acid Crime Prevention Act 2002, to prevent this kind of violence, but Bangladeshi women are still abused at a consistently high rate (Mahmood, 2004).

ii Writes Cornwall (2016, p. 3) buzzwords 'get their 'buzz' from being in-words, words that define what is on vogue'.

iii Kishore and Gupta (2004) perceive empowerment as the process by which 'the weak' gain control over their lives. In defining empowerment as a process, Smith argues that 'empowerment is basically a property of social or cultural systems rather than of individual experiences and traits' (Smith, 1989, p. 173).

iv As Kabeer (2001, p. 63) notes, 'microcredit programs for the poor have come to occupy a central place in poverty-oriented strategies in Bangladesh' (Kabeer 2001, p. 63, see also Hashemi et al 1996)

v Male householders were selected depending on the marital status of women microcredit members (that is, her husband for married women, her father/father-in laws for widowed women, and fathers or brothers for unmarried women). In the case of widowed, separated or unmarried women NELS members, the study held interviews with fathers, fathers-in-law or brothers. vi Similarly, a study conducted in the Northern part of Bangladesh by Khatun, Islam and Majumder revealed that some women could not join microcredit programs even when they were interested in doing so. One of their interviewees said: 'my husband does not like me to take loan. He would not let me get involved in such activities' (Khatun et al. 2013, p. 288).

vii The majority of the male participants, however, argued that they supported a level of freedom of movement for their wives and daughters.

viii Khatun, Islam and Majumder (2013) found that the reasons for women dropping out of microcredit programs included their dependence on their husbands, who forced them to cancel their microcredit membership or refused to allow them to join in the first place. 